\title{
KEBERMAKNAAN LEKSEM BERMAKNA ROBEK DALAM BAHASA INDONESIA
}

\author{
Hari Sulastri
}

Badan Bahasa, Kementerian pendidikan dan kebudayaan

Pos-el: sulastrihr@gmail.com

\begin{abstract}
ABSTRAK
Tulisan ini membahas tentang kebermaknaan leksem robek dalam bahasa Indonesia. Tujuan tulisan ini ialah melihat seberapa dekat kebermaknaan yang terdapat dalam leksem yang bermakna robek dalam bahasa Indonesia. Metode dan teknik dalam tulisan ini menggunakan metode deskriptif dengan kualitatif yang dilakukan melalui beberapa tahap, yaitu tahap pengumpulan data, analisis data, dan penyajian hasil analisis. Selain itu, teknik pencatan dan pengartuan dari berbagai sumber (berupa kamus) yang memuat leksem "robek'. Untuk membahas kebermaknaan dalam leksem robek, digunakan beberapa teori, seperti teori medan makna, teori kehiponoman dan kesinoniman. Dari analisis data dapat diketahui bahwa kebermaknaan sebuah leksem dapat dilihat dari komponen makna yang terdapat leksem tersbut. Kebermaknaan leksem robek dalam tulisan ini akan dapat digunakan untuk melihat hubungan yang terdapat pada leksem-leksem tersebut. Berdasarkan data dan analisis dalam penelitian ini mengimplikasikan bahwa kebermaknaan pada sebuah leksem akan dapat dijadikan dasar bagi pendefinisian sebuah leksem.
\end{abstract}

Kata Kunci: kebermaknaan, leksem, dan robek

\section{ABSTRACT}

This paper discusses the significance of leksem torn in Indonesian. The purpose of this paper is to see how close the meaningfulness contained in a meaningful leksem torn in Indonesian. Methods and techniques in this paper uses descriptive method with qualitative done in several stages, namely data collection, data analysis, and presentation of the results of the analysis. In addition, the paint of techniques and pengartuan from various sources (such as Dictionary) containing leksem 'ripped'. To discuss the significance of the leksem torn, used several theories, such as the meaning of field theory, the theory kehiponoman and synonymy. From the analysis of the data showed that the meaningfulness of a lexeme can be seen from the components of meanings leksem tersbut. Significance leksem torn in this report will be used to see the relationship contained in the lexeme-lexeme. Based on the data and analysis in this study implies that the meaningfulness of a lexeme will be used as the basis for defining a leksem.

Keywords: meaninfulness, leksem, and torn

\section{PENDAHULUAN}

Bahasa merupakan salah satu alat untuk berkomunkasi. Untuk dapat berkomunikasi dengan menggunakan bahasa seseorang memerlukan kata atau kosakata. Sebagai alat komunikasi baik lisan maupun tulisan, kata atau kosakata mempunyai makna. Dalam bahasa makna setiap, memiliki terdapat hubungan makna atau relasi makna antara kata yang satu dengan kata yang lain. Chaer (2007:128) menyatakan bahwa kata sebagai satuan kosakata mempunyai relasi kemaknaan, antara kata yang satu dengan kata yang lainnya. Selanjutnya dikatakan Chaer (2007:128) bahwa relasi makna itu dapat berupa relasi kesamaan makna (sinonimi), kebalikan makna (antonimi), ketercakupan makna (hiponimi), berlainan makna (homonimi), dan kegandaan makna (polisemi.

Sejalan dengan pendapat tersebut tulisan singkat ini mencoba menelaah salah satu relasi kebermaknaan yang berkaitan dengan ketercakupan makna (hiponimi), yakni bagaimana kebermaknaan dalam leksem yang bermakna robek dalam bahasa Indonesia. Masalah itu dikemukakan untuk dapat 
memberikan tambahan wawasan bagi pemakai bahasa yang selama ini masih banyak yang beranggapan dan berpendapat bahwa leksem-leksem yang memiliki makna robek itu bersinonim. Pada kenyataannya masing-masing leksem yang bermakna robek itu mempunyai perbedaan makna. Perbedaan dan kebersamaan yang dimiliki oleh masing-masing leksem yang terdapat dalam leksem yang bermakna robek dapat ditunjukkan dengan medan makna dan komponen makna yang terdapat pada masing-masing leksem tersebut.

Di samping itu, tulisan ini, bertujuan untuk mendeskripsikan kebermaknaan yang terdapat pada leksem yang bermakna robek. Untuk dapat menunjukkan perbedaan yang dimiliki tiap-tiap leksem yang bermakna robek, digunakan berbagai teori yang mendukung dan berkaitan dengan telaah tulisan ini. Tulisan ini juga diharapkan dapat dimanfaatkan pula bagi penyusun kamus dalam menyusun definisi lema yang berkaitan dengan leksem robek.

\section{Rumusan Masalah}

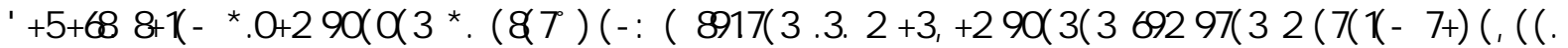

\section{B\&D\#}

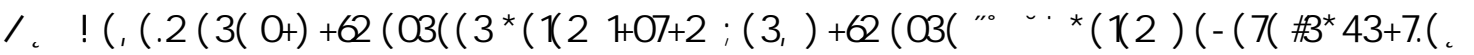

' \# Perbedaan apa sajakah yang dimiliki oleh masing-masig leksem yang terdapat dalam leksem bermakna robek.

Sejalan dengan masalah yang dikemukakan tulisan ini juga bertujuan untuk dalam mendeskripsikan leksem yang bermakna robek yang terdapat dalam bahasa Indonesia. Untuk menjawab permasalahan dan untuk mencapai tujuan tersebut, tulisan ini menggunakan berbagai pendekatan yang termaktub dalam landasan teori berikut\#

\section{Tujuan Penulisan}

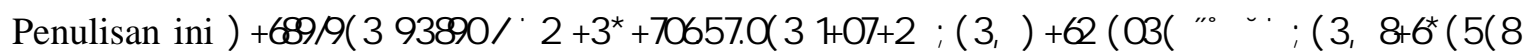
64A> 5494C4 /?6@7C4\# Untuk menjawab permasalahan yang berkaitan dengan leksem yang bermakna robek.

\section{Landasan Teoretis}

Kajian tentang kebermaknaan leksem yang bermakna robek ini berkaitan dengan berbagai teori, antara lain sebagai berikut.

\section{Teori Kehiponiman dan Kesinoniman}

Pada umumnya, kehiponiman dimaknai sebagai hubungan hierarkis yang berupa hubungan makna antara dua unit leksikal yang makna unit leksikal yang pertama merupakan bagian dari makna unit yang kedua. Misalnya. Gardena dan melati adalah hiponim dari bunga. jeruk, salak, dan apel adalah hiponim buah.

Bunga dan buah adalah superordinat atau hiperonim dari gardena dan jeruk. Saeed (1997: 69) menyatakan bahwa hubungan hiponimi adalah hubungan yang mengandung hubungan transitif. Misalnya gardena dan melati adalah hiponim dari bunga, bunga hiponim dari tanaman perdu. Hal itu dapat diartikan bahwa gardena dan melati juga merupakan hiponim dari tanaman perdu. Lyon (1996:125--130) menyatakan bahwa kehiponiman dan pertelingkahan termasuk ke dalam relasi penyulihan (substitutional relations) atau relasi paradikmatik. Sementara itu Cruse (1986: 86--95; 2000: 150). Menyatakan bahwa hubungan yang dikaitkan dengan hubungan peliputan atau inklusi adalah hubungan kehiponiman. Suatu 
hiponim dalam suatu kalimat dapat disulih atau disubtitusikan dengan hiponimnya karena makna hiponim secara tersirat terkandung dalam hiponimnya. Penyulihan merupakan cara yang biasa digunakan oleh pemakai metode kontekstual untuk menguji keanggotaan dalam kehiponiman (Lyons 1977: 292)

Berkaitan dengan kehiponiman ini, Cruse (2004: 148) menyatakan bahwa selain berhubungan secara vertikal, hiponimi juga berhubungan secara horizontal. Hubungan horizontal tersebut terdapat pada hubungan di antara sesama kohiponim yang dapat berupa hubungan semitris. Hubungan simetris di antara sesama kohiponim disebut dengan sinonim. Hubungan simetris ditandai oleh kemampuan sesama kohiponim untuk saling mengisi gatra dalam kalimat tanpa mengubah makna. Hal itu berarti jika $A$ sama dengan $B$ dan $B$ sama dengan $A$, maka $A$ dan $B$ bersinonim. Sejalan dengan pendapat itu, Chaer (2007:128) menyatakan bahwa relasi sinonim bersifat dua arah artinya kalau kata ayah bersinonim dengan kata bapak, maka kata bapak juga bersinonim dengan kata ayah. Berkaitan dengan hiponimi atau ketercakupan Chaer (2007: 128) menyebutkan bahwa dua buah kata disebut berelasi ketercakupan jika dalam kata pertama memiliki makna yang tercakup dalam makna kedua, misalnya kata merpati mempunyai relasi hiponimi dengan kata burung karena makna kata merpati tercakup ke dalam makna burung. Selanjutnya dikatakan juga bahwa dalam hubungan hiponimi bersifat searah, yaitu dari kata yang maknyanya lebih luas.

Dalam hubungan dengan analisis komponen makna, Lyons dalam Muhajir (2016:206) member batasan bahwa pendekatan analisis komponen makna adalah deskripsi makna yang didasrkan pendirian bahwa makna tiap leksim dapat dianalisis dengan sejumlah komponen (atau ciri-ciri makna) yang lebih umum. Muhajir (2016: 206) menyatakan bahwa untuk kepentingan teori dan metodologi, menyepakati konvensi notasi komponen makna seperti "binatang", "bernyawa","pemakan tetumbuhan", dicatat dengan huruf capital kecil, [BERNYAWA], [BINATANG]. Notasi tersebut dapat ditunjukan dengan contoh sebagai berikut.

\section{Wanita [KONGKRET] [BERNYAWA] [MANUSIA] [PEREMPUAN] [DEWASA] \\ Gadis [MANUSIA] [ PEREMPUAN] [DEWASA] [BELUM KAWIN]}

Lyons (1909: 318) dalam Muhajir (2016: 2007) menyatakan bahwa notasi komponen makna dengan huruf kecil itu untuk membedakan keannhya sebagai komponen makna yang memiliki konsep makna universal. Komponen makna biasanya lebih ditegaskan dengan memberikan tanda atau lambang +, (plus) jika komponen makna tertentu terdapat pada makna leksem yang dianalisis; - (minus) jika komponen makna tertentu tidak terdapat pada leksem itu, \pm (plus minus) jika komponen makna ada kemungkinan terdapat dan ada kemungkinan tidak terdapat pada makna leksem itu. Lyons (1977: 325) mengusulkan penambahan tanda 0 (nol) untuk mengungkapkan bahwa komponen makna yang bersangkutan tidak merupakan bagian dari makna leksem yang dianalisis. Perlu diperhatikan dalam penulisan komponen makna leksem yang dianalisis karena komponen makna leksem tertentu yang dipaparkan oleh seorang ahli linguistik, baik dengan bahasanya sendiri maupun dengan bahasa lain, sebenarnya muncul sebagai. Crues (2004:88-92) menyebutkan bahwa hiperonim mempunyai eksistensi yang lebih luas daripada hiponimnya. Eksistensi hiperonim menunjukkan cakupan yang lebih umum yang meliputi berbagai leksem yang lebih banyak jika dibandingkan dengan hiperonimnya. Dengan kata lain, di antara sesama anggota hiponim terdapat komponen bersama (common component) yang dikandung oleh hiperonim.

Tiap-tiap kohiponim mempunyai komponen makna khusus yang membedakannya dari kohiponim yang lain. Komponen pembeda itu disebut juga dengan komponen diagnostik (diagnostic component). Untuk menetapkan komponen bersama dan komponen pembeda, dapat dilakukan melalui analisis komponen makna.

Berkaitan dengan analisis komponen makna, Darmojuwono (2005: 121) menyatakan bahwa makna merupakan kesatuan mental pengetahuan dan pengalaman yang terkait dengan lambang bahasa yang mewakilinya. Makna terdiri atas komponen makna. misalnya makna kata wanita terbentuk dari komponen MANUSIA, DEWASA, PEREMPUAN. Selanjutnya Darmojuwono (2005: 121) menambahkan bahwa komponen makna tidak dapat dipisahkan dari pengetahuan dan pengalaman serta intuisi seseorang. Hal itu dapat diartikan bahwa untuk dapat menganalisis makna harus diketahui pula komponen makna yang terkandung di dalamnya. 
Di samping metode analisis komponen makna, untuk mendeskripsikan kebermaknaan medan makna robek dalam bahasa Indonesia juga digunakan metode penyusunan medan leksikal.

Penyusunan medan leksikal suatu leksem dapat dilakukan dengan menghubungkan tingkat bentuk dan tingkat makna. Setidaknya Lutzeier (1983: 148--76) mengajukan empat asumsi dasar yang berkaitan dengan medan leksikal itu, yaitu (1) unsur medan leksikal diturunkan dari konteks kalimat melalui proses penyulihan, (2) unsur dari medan leksikal adalah kata bukan bentuk kata. (3) medan leksikal bukan hanya sekumpulan leksem melainkan seperangkat leksem yang distrukturkan, (4) struktur itu ditentukan oleh ciri makna dari medan sebagai suatu keseluruhan dan ciri tiap unsur sebagai ciri khusus.

Selanjutnya teori medan makna dan medan leksikal akan digunakan dalam menganalisis data medan makna kata robek dalam bahasa Indonesia.

\section{Teori Medan Makna}

Dalam teori medan makna disebutkan bahwa setiap leksem mempunyai sistem leksikal yang khas. Setiap leksem juga dibatasi oleh hubungan makna antara leksem yang satu dengan yang lainnya. Saeed (2003: 63) dalam Muhajir (2016: 93) member batasan bahwa medan makna adalaha sekelompok leksem yang tergolong aktivitas yang sama atau himpunan pengetahuan para spesialis, seperti kata-kata yang bertalian makna masak-memasak, pakaian, furnitur, dan sebagainya. Makna leksem dibatasi oleh hubungan makna antara leksem yang satu dengan leksem yang lain. Untuk mendeskripsikan hubungan antarleksem, tiap makna leksem dapat dianalisis ke dalam komponen diagnostik makna atau ciri pembeda makna yang lebih kecil.

Porzig dalam (Basiroh, 1992: 17) mengajukan teori medan makna dengan memperhitungkan hubungan secara sintagmatis. Medan makna tersebut terutama berhubungan dengan verba dan adjektiva. Leksem cubit, misalnya secara sintagmatis dihubungkan dengan tangan. Leksem cabak, cabik, cabir, camping, carik, dan robek dikelompokkan dalam satu medan karena secara sintagmatis ketiganya dapat dihubungkan dengan leksem robek.

Lyons (1977: 268) menyatakan bahwa leksem yang berhubungan secara paradigmatis dan sintagmatis di dalam suatu bahasa dapat dikatakan menjadi unsur dari medan yang sama, dan medan yang mempunyai unsur berupa leksem adalah sebuah medan leksikal. Suatu medan leksikal merupakan subperangkat dari kosakata. Hal yang perlu diperhatikan adalah perlunya dicatat konteks tempat leksem itu muncul yang menunjukkan keannya dalam medan leksikal yang bersangkutan (Lyons 1977: 269 dan Cruse 1986: 1).

Penentuan seperangkat leksem sebagai suatu medan leksikal umumnya hanya didasarkan pada intuisi (Lutzeier 1983: 147). Adapun Cruse (2004) mencoba menyusun medan leksikal tanpa terlalu bergantung pada intuisi. Berkaitan dengan medan leksikal dan medan makna Kridalaksana (2008: 151) menyatakan bahwa medan makna merupakan bagian dari sistem semantik bahasa yang menggambarkan bagian bidang kehidupan atau realistas dalam alam semesta tertentu dan yang direalisasikan oleh seperangkat unsur leksikal yang maknanya berhubungan. Selanjutnya, Kridalaksana (2008: 15) menggambarkan medan makna itu, misalnya warna membentuk medan makna tertentu, begitu pula nama perabot rumah tangga, resep makanan dan minuman, dan peristilahan penerbangan.

Verhaar (2010: 390) menyebutkan bahwa setiap bahasa, banyak kata tidak memiliki maknanya sendiri-sendiri, lepas dari makna kata-kata lainnya, tetapi memiliki makna yang berperanan hanya karena hubungannya dengan kata-kata lainnya. Selanjutnya dikatakannya bahwa ada sistem pembeda atau identitas pembeda, menurut sistem perbedaan yang khas untuk setiap bahasa. Unsur pembeda ini juga berlaku pada hubungan antarkata secara sitemantis, misalnya dalam kelompok unsur-unsur leksikal tertentu. Analistik semantik leksikal terhadap unsur-unsur leksikal dalam linguistik dikenal dengan analistik komponensial (Verhaar, 2010: 391).

Selanjutnya teori medan makna dan medan leksikal akan digunakan dalam menganalisis data medan makna kata robek dalam bahasa Indonesia. 


\section{METODE DAN TEKNIK}

Pengumpulan data pada tulisan ini dilakukan dengan teknik pencatan dan pengartuan dari berbagai sumber (berupa kamus) yang memuat leksem "robek'. Metode pengumpulan data dalam penelitian ini mengikuti prosedur yang dikemukakan oleh dikemukakan Sudaryanto dalam Indiastini (2008: 10), yaitu tahap pengumpulan data, analislis data, dan penyajian hasil analisiss data. Sumber data penelitian ini aialah Kamus Besar Bahasa Indonesia, edisi IV, cetakan ketujuh, tahun 2014 dan Kamus Umum Bahasa Indonesia (Poerwadarminta, 1987). Selanjutnya data yang terkumpul diklasifikasi berdasarkan kepemilikan komponen maknanya.

Metode yang digunakan untuk membahas kebermaknaan dalam tulisan ini ialah metode deskriptif dengan kualitatif yang dilakukan melalui beberapa tahap sebagai berikut.

Data yang sudah terkumpul dan diklsifikasikan dicermati berdasarkan komponen maknanya. Pencermatan dilakukan dengan cara mengontraskan kepemilikan komponen makna bersama (share meaning) dan komponen spesifik (specific meaning). Berdasarkan pada hasil tersebut dapat disusun kepemilikan makna pada masing-masing leksem. Dalam pendeskripsian komponen makna digunakan teknik penandaan komponen makna. Misalnya kepemilikan komponen makna dapat ditandai dengan tanda (+) yang dapat diartikan memiliki komonen makna; tanda (-) dapat diartikan tidak memiliki komponen makna; dan tanda ( \pm ) dapat diartikan bias memiliki bisa tidak. Analisis data dalam penelitian ini juga dilakukan dengan metode distribusioanal yang dikemukakan Sudaryanto (dalamndiastini, 2 008: 10) yang menyatakan bahwa metode ini menggunakan unsur bahasa itu sendiri sebagai alat penentu pembuktiannya.

\section{PEMBAHASAN}

Pembahasan tentang kebermaknaan leksem robek dalam bahasa Indonesia dapat ditunjukkan dengan uraian berikut. Selain itu, pada bagian berikut juga tampak hierarki leksem robek sebagai penyusun kebermaknaan leksikal leksem robek. Berikut adalah uraian lebih lanjut.

\section{Temuan Data}

Leksem yang berkaitan dengan leksem robek diperoleh melalui konteks berikut ini. Dari konteks itu didapat perangkat kata yang berbeda. Leksem yang berkaitan dengan leksem robek mencakupi y.

(1) Ia memakai baju y dijahitannya.

(2) Bajunya y karena ter...

(3) Daun pisang itu y karena tiupan angin yang kencang.

(4) Karena berebut, buku itu menjadi y.

(5) Uang itu y di pinggirnya.

Pengisi y dalam konteks tersebut digunakan untuk leksem yang berhubungan dengan adjektiva robek.

Dari konteks (1) diperoleh perangkat bentuk kata yang berhubungan secara paradikmatis dengan y sebagai berikut.

Leksem yang berkaitan dengan robek mencakupi sobek, cabik, cabir, cobar-cabir, cabik, koyak, rombeng, sobek

Dari konteks (2) diperoleh perangkat kata seperti robek, sobek, dan koyak

Dari konteks (3) diperoleh seperangkat kata seperti, cabik, koyak-koyak, dan sobek-sobek

Dari konteks (4) diperoleh seperangkat kata, seperti robek, robak-rabit

Dari konteks (5) diperoleh seperangkat kata seperti suwir-suwir.

\section{Analisis Komponen Makna}

Berkaitan dengan analisis komponen ini, adanya unsur-unsur pembedadan unsur yang sama dalam sebuah leksem, dapatlah disusun analisis komponen makna yang terdapat dalam sebuah sebuah leksem.

Dalam kaitannya dengan penelitian ini, para penyusun kamus banyak memberikan informasi tentang leksem-leksem yang berkaitan dengan leksem robek ini. Hal itu dapat diuraikan sebagai berikut. 
Berdasarkan komponen makna yang dimiliki oleh masing-masing leksem dapat diketahui bahwa ada leksem yang mempunyai komponen makna bersama. Misalnya ada komponen makna bersama yang terdapat pada leksem cabik, koyak, robek, dan sobek 'robek secara memanjang atau melebar,panjang atau lebar'

Ada pula komponen makna busana untuk leksem cabir, cabir-cabir, suwir, suwir-suwir 'robek panjang'. Komponen makna yang terdapat pada leksem koyak, cabik robek, sobek 'robek memanjang'. Komponen makna bersama leksem rombeng, compang-camping, cobak-cabik, 'robek karena sudah tua'. Apabila diperhatikan, maka akan tampak bahwa komponen makna bersama pada keempat kelompok tersebut memiliki bentuk robek yang berbeda. Leksem cabir, koyak, rombeng mempunyai komponen makna bersama robek memanjang. Bentuk atau keadaan benda itu robek 'terlepas, terputus, terpisah dari anyaman (jahitannya, tenunanya) secara memanjang (tentang benda tipis)'. Leksem cabir, cabir-cabir, suwir, suwir-suwir mempunyai komponen makna bersama bentuk 'robek memanjang'. Leksem rombeng, compang-camping, cabik-cabik mempunyai komponen bersama pada 'robek karena sudah tua.'

Berdasarkan komponen makna bersama yang terdiskripsi dalam kamus, dapat dianalisis hubungan makna di antara leksem yang berkaitan dengan leksem atau adjektiva robek. Dari deskripsi dan analisis tersebut tampak bahwa ada beberapa sudut pandang yang dapat dijadikan sebagai pedoman untuk melihat hubungan makna di antara leksem-leksem tersebut. Dalam makalah ini, bentuk atau keadaan robek yang disimpulkan dari komponen bersama digunakan untuk menyusun pengelompokan leksem yang berkaitan dengan leksem robek.

Ada beberapa keadaan robek, dan keadaan robek lain dapat dijadikan pedoman untuk mengelompokkan leksem-leksem yang berkaitan dengan leksem robek. Keadaan atau bentuk pertama adalah robek memanjang untuk benda yang lebar, misalnya kain, permadani. Dilihat dari usia bahan yang robek ada bahan yang sudah dimakan usia atau sudah lama. Dilihat bentuk robekannya ada yang berbentuk memanjang, melebar, dan tidak beraturan. Medianya juga berbeda-beda, misalnya kain, kertas, dan permadani. Bagian yang robek juga ada diberbagai tempat, misalnya ada yang di tepi dan berbagai tempat lain.

Berdasarkan pada informasi data dan informasi makna leksem yang terdapat kamus, kata atau leksem yang termasuk dalam kata robek adalah sebagai berikut.

cabak $a$ koyak yang lebar

cabik $a$ koyak (robek, sobek ) panjang

cabir $a$ robek panjang; koyak; cabik

caing $a$ cabik; koyak

camping $a$ koyak (robek, sobek ) panjang; cabik

carik 1 a cabik; robek; $2 n \ldots$.

cobar-cabir $a$ koyak pada beberapa tempat; cabik-cabik

compang-camping $a$ koyak-koyak memanjang

compeng /compéng/ a sobek-sobek (koyak-koyak) pada tepinya (tentang pakaian, kertas, dsb)

corak-carik $a$ banyak cariknya; koyak-koyak; cabik-cabik

cuang-caing a cabik-cabik; koyak-koyak; caing-caing

koyak $a$ cabik; robek; sobek

rabak $a$ terlepas, terputus, terpisah dari jahitannya, atau tenunanya secara memanjang atau melebar; koyak(robek) panjang atau lebar

robak-rabik $a$ robek-robek; koyak-koyak (tentang tikar, baju, permadani)

robat-rabit $a$ sobek-sobek; robak-rabik

robek /robék/ a terlepas, terputus, terpisah dari anyaman (jahitannya, tenunanya) secara memanjang (tentang benda tipis); sobek

rombang-rambing $a$ robak-rabik; cabik-cabik

rombeng /rombéng/ $a$ compang-camping; sobek karena sudah tua

rompang $a$, rompang-romping a rombang-rambing; compang-camping

sobek//robék/ a cabik; robek; koyak

suwir, suwir-suwir a robek panjang 
Leksem yang berkaitan dengan leksem robek dapat disusun hierakhi sebagai beraikut.

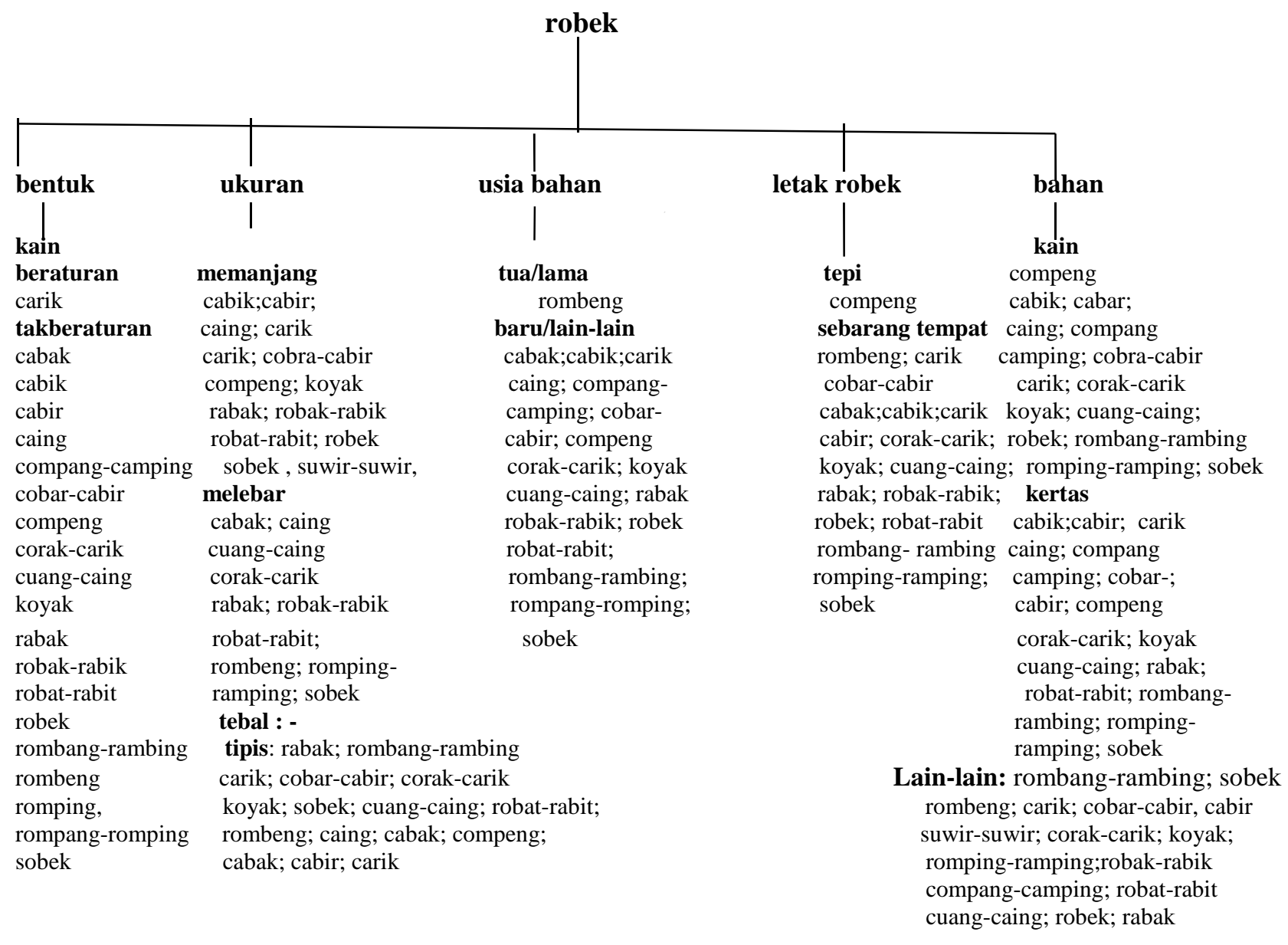

\section{Bagan Analisis Komponen Makna}

Berdasarkan komponen makna yang dimiliki oleh tiap leksem dapat diperinci dan disusun analisis, komponen maknanya sebagai berikut.

Berdasarkan pada gabungan komponen makna dari berbagai bentuk atau keadaan robek, dan tempat yang lain leksem yang tercakup dalam leksem robek dapat dianalisis sebagai berikut.

Dari bentuk robek terdapat komponen makna beraturan (misalnya carik) dan tidak beraturan (misalnya compang-camping, robak-rabik, robat-rabit, koyak, rombang-rambing, rombeng.)

Dari ukuran robek terdapat komponen memanjang (misalnya, carik, cobra-cabir, compeng, koyak, robat-rabit; robek ); melebar (misalnya, cabak; caing, carik, cobra-cabir, robat-rabit); tebal (tidak ada), dan tipis (misalnya, koyak; sobek; cuang-caing; robat-rabit; koyak; sobek; rombeng; caing; cabak; compeng)

Dari usia atau umur bahan lama (misalnya, rombeng), baru termasuk lain-lain (tidak lama, tetapi juga bukan bahan yang baru), misalnya .

Dari letak robek pada bahan di tepi bahan (misalnya, compeng ) dan di sebarang tempat (misalnya, rombeng; carik, cobar-cabir, koyak; cuang-caing, romping-ramping) 
Dari bahan yang robek terdapat komponen makna kertas (misalnya, camping; cobar-cabir, corakcarik; koyak, rombang-rambing; romping-ramping; sobek); kain (misalnya compeng, cabik; cabar, koyak; cuang-caing), dan lain-lain misalnya daun (misalnya sobek), permadani atau baju (misalnya, robak-rabik, robek-robek; koyak-koyak, daun (misalnya suwir-suwir) sebagai berikut.

Berdasarkan pada hasil analisis komponen makna dapat disusun sebagai komponen makna

\begin{tabular}{|c|c|c|c|c|c|c|c|c|c|c|c|c|c|}
\hline \multirow[b]{2}{*}{ Entri } & \multicolumn{2}{|c|}{ Bentuk } & \multicolumn{4}{|c|}{ Ukuran } & \multicolumn{2}{|c|}{$\begin{array}{c}\text { Usia } \\
\text { Bahan }\end{array}$} & \multicolumn{3}{|c|}{ Bahan } & \multicolumn{2}{|c|}{$\begin{array}{l}\text { Letak } \\
\text { robek }\end{array}$} \\
\hline & $\begin{array}{l}\text { Ber } \\
\text { atur } \\
\text { an }\end{array}$ & $\begin{array}{l}\text { Tak } \\
\text { Ber } \\
\text { atur } \\
\text { an }\end{array}$ & $\begin{array}{l}\text { Me- } \\
\text { man } \\
\text { jang }\end{array}$ & $\begin{array}{l}\text { Mele- } \\
\text { bar }\end{array}$ & $\begin{array}{l}\text { Te- } \\
\text { bal }\end{array}$ & $\begin{array}{l}\text { Ti- } \\
\text { pis }\end{array}$ & $\begin{array}{l}\text { Tua/ } \\
\text { lama }\end{array}$ & $\begin{array}{l}\text { Baru/ } \\
\text { lain- } \\
\text { lain }\end{array}$ & $\begin{array}{l}\text { Ka- } \\
\text { in }\end{array}$ & $\begin{array}{l}\text { Ker } \\
\text { tas }\end{array}$ & $\begin{array}{l}\text { Lain- } \\
\text { lain }\end{array}$ & $\begin{array}{l}\text { Di } \\
\text { tepi }\end{array}$ & $\begin{array}{l}\text { Seba } \\
\text { rang } \\
\text { temp } \\
\text { at }\end{array}$ \\
\hline cabak & - & + & - & + & - & + & - & \pm & + & + & + & - & + \\
\hline cabik & - & + & + & - & - & + & - & \pm & + & + & + & - & + \\
\hline cabir & - & + & + & - & - & + & - & \pm & + & + & + & - & + \\
\hline caing & - & + & + & \pm & - & + & - & \pm & + & + & + & - & + \\
\hline $\begin{array}{l}\text { compang- } \\
\text { camping }\end{array}$ & - & + & - & \pm & - & + & - & \pm & + & + & + & - & + \\
\hline carik & + & - & + & - & - & + & - & \pm & + & + & + & - & + \\
\hline $\begin{array}{l}\text { cobar- } \\
\text { cabir }\end{array}$ & - & + & \pm & - & - & + & - & \pm & + & + & + & - & + \\
\hline compeng & - & + & + & - & - & + & - & \pm & + & + & $\begin{array}{lll}+ & & \end{array}$ & + & + \\
\hline $\begin{array}{l}\text { corak- } \\
\text { carik }\end{array}$ & - & + & - & \pm & - & + & - & \pm & + & + & + & - & + \\
\hline $\begin{array}{l}\text { cuang- } \\
\text { caing }\end{array}$ & - & + & - & \pm & - & + & - & \pm & + & + & + & - & + \\
\hline koyak & - & + & \pm & \pm & - & + & - & \pm & + & + & + & - & + \\
\hline rabak & - & + & \pm & \pm & - & + & - & \pm & + & + & + & - & + \\
\hline $\begin{array}{l}\text { robak- } \\
\text { rabik }\end{array}$ & - & + & \pm & \pm & - & + & - & \pm & - & + & + & - & + \\
\hline $\begin{array}{l}\text { robat- } \\
\text { rabit }\end{array}$ & - & + & \pm & \pm & - & + & - & \pm & - & + & + & - & + \\
\hline robek & - & + & + & - & - & + & - & \pm & + & + & + & - & + \\
\hline $\begin{array}{l}\text { rombang- } \\
\text { rambing }\end{array}$ & - & + & - & + & - & + & - & \pm & + & + & + & - & + \\
\hline rombeng & - & + & - & + & - & + & + & - & + & + & + & - & + \\
\hline $\begin{array}{l}\text { romping, } \\
\text { rompang- } \\
\text { romping }\end{array}$ & - & + & - & + & - & + & - & \pm & + & + & + & - & + \\
\hline $\begin{array}{l}\text { suwir- } \\
\text { suwir }\end{array}$ & + & - & + & - & - & + & - & \pm & - & - & + & - & + \\
\hline sobek & - & + & + & \pm & - & + & - & \pm & + & + & + & - & + \\
\hline
\end{tabular}

Dari uraian bagan dan heirarkhi tersebut leksem robek merupakan leksem yang bersifat umum.

Dari analisis komponen makna tersebut juga tampak adanya leksem yang diapat dipandang sebagai bersinonim parsial, seperti koyak, robek, dan sobek.

Berdasarkan analisis komponen makna tersebut terdapat persamaan pada kebermaknaan pada leksem robek, yaitu leksem yang merupakan bentuk perulangan pada umunya keadan robek selalu tidak beraturan. Bahan benda robek pada umumnya merupakan bahan yang tipis. 


\section{SIMPULAN}

Berdasarkan pada uraian tersebut di atas dapat ditarik kesimpulan bahwa leksem robek dalam bahasa Indonesia mempunyai berbagai macam bentuk, tempat, usia bahan, dan bahan yang berbeda. Berdasarkan data yang ditemukan dalam kajian singkat ini diketahui bahwa leksem-leksem yang terkait dalam leksem robek mempunyai perbedaan dalam hal kepemilikan komponen makna, sehingga hubungan yang terdapat pada leksem-leksem tersebut merupakan hubungan yang bersifat hierarkis. Dapat pula dikatakan bahwa leksem-leksem tersebut membentuk hubungan kehiponiman. Akan tetapi, ada pula leksem yang dapat dipandang sebagai hubungan bersinonim parsial, seperti koyak, robek, dan sobek. Ada beberapa leksem yang dipandang sebagai bersinonim ternyata memiliki perbedaan dalam kepemilikan komponen maknanya sehingga tidak dapat dimasukkan dalam hubungan kesinoniman, misalnya leksem rombeng dan compeng (keduanya merupakan kohiponim dari leksem robek dan tidak bersinonim). Demikian juga dengan romping-ramping dan robak-rabik. Bentuk perulangan pada leksem atau kosakata robek menunjuukan bahwa benda yang robek selalu tidak beraturan. Benda yang robek pada umumnya adalah benda yang berukuran tipis.

Pengetahuan tentang hubungan relasi makna merupakan hal yang penting bagi penyusun kamus, buku ajar, atau penyusun tesaurus.

\section{Implikasi}

Berdasarkan hasil analisis dalam kajian ini ada beberapa implikasi yang dapat terjadi, yaitu kebermaknaan sebuah leksem pada sebuah data dapat dijadikan sumber informasi yang akan dapat digunakan sebagai salah satu cara untuk membuat definisi sebuak leksem.Pendefinisia leksem yang tidak memperhatikan kebermaknan leksem yang vtidak didasarkan pada medan makna akan memberikan informasi yang tidak jelas. Di samping itu juga akan terjadi ketidakcermatan dalam pemakaiaan kata yang berhiponim atau yang bersinonim.

Pendefinisian yang cermat dan tepat dapat memberikan informasi jelas dan tepat bagi pemakainnya. Pengetahuan tentang kebermaknaan sebuah leksem yang didasarkan pada hubungan relasi makna merupakan hal yang penting bagi penyusun kamus, buku ajar, atau penyusun tesaurus. Hal itu akan memudahkan dalam penyususnan definisi dan juga memudahkan dalam penyusunan berdasarkan tematik. 


\section{DAFTAR PUSTAKA}

Basiroh, Umi. 1992. "Telaah Baru dalam Tata Hubungan Leksikal Kehiponiman dan Kemeroniman”. Tesis Magister Universitas Indonesia.

Chaer, Abdul. 2007. Leksikologi dan Leksikografi Indonesia. Jakarta: Rineka Cipta.

Cruse, Alan. 1986. Lexical Semantics. New York: Cambridge University Press.

Cruse, Alan. 2000. Meaning in Language: An Introduction to Semantics and Pragmatics. Oxford dan New York: Oxford University Press.

Crues, Alan. 2004. Meaning in Language: An Introduction to Semantics and Pragmatics. Second Edition. New York: Oxford University Press.

Darmojuwono, Setiawati. 2005. "Semantik". Dalam Pesona Bahasa: Langkah Awal Memahami Linguistik. Jakarta: Gramedia Pustaka Utama.

Indiastini, Titik. 2008. Partisipan Dalam Novel Kinanti: Sebuah Studi Kasus Eacana Naratif Berbahasa Jawa. Yogyakarta: Grafindo Literamedia.

Kridalaksana, Harimurti. 2008. Kamus Linguistik. Edisi Keempat. Jakarta: Gramedia Pustaka Utama.

Lyons, John. 1986. Introduction to Theoritical Linguistics. Cambridge: Cambridge University Press.

Lyons, 1977. Semantics I-II. Cambridge: Cambridge University Press.

Muhadjir. 2016. Semantik dan Pragmatik. Tangerang: Pustaka Mandiri.

Poerwadarminta, W.Y.S.1987. Kamus Umum Bahasa Indonesia. Jakarta: Balai Pustaka.

Saeed, John. I. 2003. Semantics. New York: Blackwell Publishing.

Tim Penyususun Kamus Besar Bahasa Indonesia. 2014. Kamus Besar Bahasa Indonesia. Edisi Keempat. Cetakan Ketujuh. Jakarta: Gramedia Pustaka Utama.

Verhaar. J.W.M. 2010. Asas-Asas Linguitik Umum. Cetakan Ketujuh. Yogyakarta: Gadjah Mada University Press. 